\title{
Sodium/Nucleoside Cotransporter 2
}

National Cancer Institute

\section{Source}

National Cancer Institute. Sodium/Nucleoside Cotransporter 2. NCI Thesaurus. Code

C113320.

Sodium/nucleoside cotransporter 2 ( $658 \mathrm{aa}, \sim 72 \mathrm{kDa}$ ) is encoded by the human SLC28A2 gene. This protein is involved in purine nucleoside transport. 